\title{
Penerapan Model Discovery Based Learning (DBL) Berbantuan Geogebra Untuk Meningkatkan Hasil Belajar Siswa Kelas IXB SMP Negeri 4 Yogyakarta Materi Transformasi Semester 1 Tahun Pelajaran 2018/2019
}

\author{
Wahyu Cahyaning Pangestuti
}

SMP Negeri 4 Yogyakarta

\begin{abstract}
The purpose of this study is to describe the application of Discovery Based Learning (DBL) assisted by GeoGebra software that can improve the learning outcomes on transformation material of Class IXB students of SMP 4 Yogyakarta Junior High School in the first semester of academic year 2018/2019. The research method used was classroom action research which consisted of four stages, namely planning, implementation, observation, and reflection. The research subjects were all IXB grade students, consisted of 34 students, while the research object was the whole process and results of mathematics learning with the application of learning using DBL assisted by GeoGebra to improve students' learning outcomes. The research instruments were researchers, student activity observation sheets, observation sheets for teacher learning activities, student motivation questionnaire sheets, pretests, posttests, documentation, and field notes. Data analysis techniques used qualitative descriptive data analysis through three stages, namely reduction, analysis and inference of data. This research was conducted in two cycles. The results showed that the learning outcomes of Class IXB students of SMP 4 Yogyakarta Junior High School in in the first semester of academic year 2018/2019 were improved using DBL assisted by GeoGebra. The average of pretest cycle 1 was 31, 68. The average of posttest was 94.09. The increase was 62.41. The average pretest cycle 2 was 30, 88. The average posttest was 93.38. The increase was 62.50. The increase was higher than the indicator of research success, which was 50.00.
\end{abstract}

Keywords: discovery based learning, GeoGebra software, learning outcomes

\section{Pendahuluan}

Arus globalisasi disertai dengan perkembangan teknologi yang semakin canggih kini memasuki era revolusi industri 4.0, yakni menekankan pada pola digital economy, artificial intelligence, big data, robotic, dan lain sebagainya atau dikenal dengan fenomena disruptive innovation. Menghadapi tantangan tersebut, pengajaran di sekolah pun dituntut untuk berubah, untuk menghadirkan pendidikan berkualitas era revolusi 4.0 tersebut bagi generasi masa depan.

Pendidikan merupakan hal penting untuk menghadapi perkembangan di era globalisasi seperti saat ini. Seiring dengan kemajuan ilmu pengetahuan dan teknologi, pendidikan di Indonesia juga terus mengalami perkembangan menuju ke arah perbaikan untuk meningkatkan kualitas pendidikan. Pemerintah telah memberikan perhatian khusus dalam hal sistem pendidikan di Indonesia antara lain dengan melakukan pembaharuan metode mengajar, perbaikan buku-buku pelajaran, dan pembaharuan kurikulum.

Kurikulum yang saat ini diterapkan dan dikembangkan oleh pemerintah adalah Kurikulum 2013. Dalam penerapannya, guru tidak hanya sebagai sumber belajar saja, melainkan berperan sebagai pembimbing dan fasilitator agar siswa 
mau dan mampu belajar. Siswa tidak lagi diposisikan sebagai objek belajar, melainkan siswa diposisikan sebagai subjek yang belajar sesuai bakat, minat, dan kemampuan yang dimilikinya. Proses pembelajaran seperti inilah yang disebut pembelajaran berpusat kepada siswa (student centered) (Sanjaya, 2008).

Pembelajaran di dalam kelas merupakan bagian yang sangat penting dari proses pendidikan. Jika pelaksanaan pembelajaran di kelas bermutu akan menghasilkan output yang berkualitas. Guru memiliki peran yang sangat besar dalam mengorganisasikan kelas sebagai bagian dari proses pembelajaran dan siswa sebagai subjek yang sedang belajar.

Kemampuan guru dalam mengemas suatu rancangan pembelajaran yang bermutu tentu diawali dari persiapan mengajar yang matang. Adanya perubahan paradigma dalam proses pembelajaran dimana kegiatan belajar mengajar tidak berpusat pada guru lagi melainkan berpusat pada siswa diharapkan dapat mendorong siswa untuk terlibat lebih aktif dalam membangun pengetahuan, sikap, dan perilakunya (Afiatin, 2011). Hal ini sejalan dengan salah satu prinsip pembelajaran yaitu keterlibatan langsung/berpengalaman. "Prinsip ini (Prinsip Keterlibatan Langsung/ Berpengalaman) berhubungan dengan prinsip aktivitas, bahwa setiap individu harus terlibat secara langsung untuk mengalaminya" (Tim pengembang MKDP, 2011).

Matematika merupakan salah satu mata pelajaran yang dipelajari pada semua jenjang pendidikan, yaitu dari sekolah dasar sampai jenjang perguruan tinggi. Hal ini antara lain karena matematika dapat digunakan secara universal dalam segala bidang kehidupan manusia terutama ilmu pengetahuan dan teknologi. Tetapi sayangnya, menurut pengalaman penulis, sebagian besar siswa menganggap matematika sebagai pelajaran yang sulit dipelajari. Salah satu penyebabnya, dalam proses pembelajarannya sering disajikan dalam bentuk formal dan abstrak. Sifat abstrak ini menyebabkan banyak siswa mengalami kesulitan dalam memahami materi matematika. Materi kelas IX semester 1 sebelum Penilaian Tengah Semester (PTS) bersifat abstrak yaitu: (1) Bilangan berpangkat dan bentuk akar; (2) Persamaan kuadrat dan (3) Fungsi kuadrat.

Dari hasil PTS semester 1 tahun ajaran 2018/2019, rata-rata untuk mata pelajaran matematika dari 5 kelas, kelas IXA s.d. IXE adalah 56,70. Hasil ini relatif jauh lebih rendah dari Kriteria Ketuntasan Minimal (KKM) sekolah yaitu 80. Ratarata terendah dari 5 kelas tersebut adalah kelas IXB yaitu 46,09. Hasil ini tentu harus segera ditindaklanjuti, agar nilai siswa meningkat pada materi selanjutnya setelah PTS terutama kelas IXB. Materi selanjutnya setelah PTS adalah Transformasi.

Kurikulum 2013 menyebutkan bahwa salah satu materi geometri yang harus diajarkan kepada siswa SMP kelas IX ialah materi transformasi. Materi transformasi merupakan salah satu materi matematika yang membutuhkan strategi/model/ pendekatan pembelajaran dan media dalam membelajarkannya. Hal ini dikarenakan konsep transformasi adalah konsep yang abstrak dan baru diajarkan kepada siswa SMP kelas IX. Sehingga konsep ini dapat dibayangkan dan diterima oleh siswa. Contoh kegunaan konsep ini dalam kehidupan sehari-hari, misalnya dalam prinsip eskalator, lift, navigasi, dan lain sebagainya.

Dengan harapan mudah diterima dan dipahami siswa, mata pelajaran 
matematika bisa disajikan tidak formal dan didekatkan dengan kehidupan sehari-hari siswa, seperti dengan penerapan model pembelajaran Discovery Based Learning, Problem Based Learning, Project Based Learning, Cooperative Learning, Differentiated Instruction, dan Open-Ended. Selain itu dapat juga menggunakan media pembelajaran seperti Powerpoint, flowchart, Software pembelajaran GeoGebra dan lain-lain. Alat peraga yang dekat dengan kehidupan sehari-hari siswa juga dapat digunakan, seperti eskalator, lift, navigasi, dan lain sebagainya.

Menurut Roestiyah (2001: 20), discovery learning ialah suatu cara mengajar yang melibatkan siswa dalam proses kegiatan mental melalui tukar pendapat, dengan diskusi, seminar, membaca sendiri dan mencoba sendiri, agar anak dapat belajar sendiri. Siswa secara aktif menemukan sendiri konsep-konsep dalam pembelajaran dengan pengarahan secukupnya dari guru. Proses penemuan ini dapat dilakukan dengan berbagai cara, salah satunya dengan melakukan kegiatan praktikum di laboratorium. Hal ini sesuai dengan yang disampaikan oleh Kolb (1984), bahwa pengetahuan secara terus-menerus diperoleh dari pengalaman dan pengujian oleh individu. Pembelajaran discovery learning memungkinkan proses pembelajaran yang lebih bermakna sehingga tertanam dengan baik dalam pengetahuan yang diperoleh siswa (De Jong \& Joolingen, 1998: 194).

GeoGebra adalah sebuah aplikasi komputer yang diciptakan untuk mempermudah pembelajaran matematika, khususnya dalam materi geometri, aljabar dan kalkulus. (Judith, markus hohenwarter and team, 2008: 8). Dalam penggunaan GeoGebra ini, guru bisa langsung menggambar sekaligus menerangkan bangun yang ingin dijelaskan pada anak didiknya. Di sini aplikasi GeoGebra berperan sebagai media pembelajaran. Diharapkan pula GeoGebra bisa menarik perhatian dari siswa sehingga dapat memacu semangat belajar dari dalam diri siswa.

Berdasarkan uraian di atas, sangat penting dilaksanakan tindakan agar nilai siswa meningkat dan pemahaman terhadap materi transformasi yang tergolong abstrak menjadi lebih baik. Dengan demikian dilaksanakan penelitian tindakan kelas dengan judul "Penerapan Model Discovery Based Learning (DBL) Berbantuan GeoGebra untuk Meningkatkan Hasil Belajar Siswa Kelas IXB SMP Negeri 4 Yogyakarta Materi Transformasi Semester 1 Tahun Pelajaran 2018/2019".

\section{Metode Penelitian}

a. Setting Penelitian

Penelitian ini dilakukan selama 6 bulan, Juli s.d. Desember 2018 mulai dari persiapan sampai laporan. Khusus pada saat tindakan dilaksanakan pada Bulan Oktober. Hal ini dilakukan karena sesuai program tahunan dan program semester materi transformasi dibahas pada bulan tersebut.

Jadwal penelitian mulai dari menyusun proposal sampai akhir penyusunan laporan penelitian dilaksanakan sekitar 6 bulan. Dilaksanakan pada semester ganjil tahun pelajaran 2018/2019. Penyusunan proposal menghabiskan waktu 2 bulan, penyiapan instrumen 6 minggu, praktik penelitian 3 minggu, dan penyusunan pelaporan 2,5 bulan. Pelaksanaan penelitian dilaksanakan dengan 2 siklus. Siklus 1 dan 2 masing-masing dilakukan dengan tiga pertemuan

Penelitian itu dilakukan di SMP Negeri 4 Yogyakarta, Jalan Hayam Wuruk 
nomor 18 Yogyakarta. Penelitian dilakukan di sekolah ini karena sehari-hari peneliti bekerja sebagai guru matematika pada instansi ini.

\section{b. Subjek Penelitian}

Subjek penelitiannya adalah siswa kelas IXB SMP Negeri 4 Yogyakarta. Kelas ini terdiri dari 20 siswa perempuan dan 14 laki-laki sehingga jumlah seluruhnya 34 siswa. Latar belakang orang tua siswa rata-rata berpenghasilan menengah ke bawah.

Kelas IX di sekolah ini terdiri dari 5 kelas, kelas IXA s.d. IXE, dengan jumlah siswa 168 orang. Sekolah relatif terletak di tengah Kota Yogyakarta dan di pinggir jalan utama yaitu Jalan Hayam Wuruk. Sebelah utara berbatasan dengan STIE Isti Ekatama Upaweda. Di sebelah selatan ada minimarket, sebelah timur terdapat rumah-rumah penduduk, serta di seberang Jalan Hayam Wuruk sebelah barat terdapat Gedung Dinas Pendidikan Kota Yogyakarta.

\section{c. Prosedur Penelitian}

Penelitian ini dilakukan dengan menggunakan metode Penelitian Tindakan Kelas (PTK) terdiri dari 2 siklus. Model penelitian yang diambil adalah model PTK menurut Kemmis \& McTaggart. Model yang dikemukakan Kemmis \& Taggart merupakan pengembangan lebih lanjut dari model Kurt Lewin. Secara mendasar tidak ada perbedaan yang prinsip antara keduanya. Model ini banyak dipakai karena sederhana dan mudah dipahami. Rancangan Kemmis \& Taggart dapat mencakup sejumlah siklus, masing-masing terdiri dari tahap-tahap: perencanaan (plan), pelaksanaan dan pengamatan (act \& observe), dan refleksi (reflect). Tahapan-tahapan ini berlangsung secara berulang-ulang, sampai tujuan penelitian tercapai.
Penelitian ini dilaksanakan dengan 2 siklus, setiap siklus terdiri dari empat tahapan yaitu: (1) Perencanaan (planning), (2) Pelaksanaan (acting), (3) Pengamatan (observing), dan (4) refleksi (reflecting).

\section{d. Sumber Data}

Data adalah catatan atas kumpulan fakta. Dalam penggunaan sehari-hari data berarti suatu pernyataan yang diterima secara apa adanya. Pernyataan ini adalah hasil pengukuran atau pengamatan suatu variabel yang bentuknya dapat berupa angka atau kata-kata. Sumber data adalah siswa kelas IXB SMP Negeri 4 Yogyakarta. Tempat penelitian di ruang kelas IXB SMP Negeri 4 Yogyakarta Jalan Hayam Wuruk 18 Yogyakarta. Data disajikan berupa huruf-huruf, angka, gambar dan simbol.

\section{e. Teknik dan Alat Pengumpul Data}

Teknik pengumpulan data: pre tes, pos tes, observasi kegiatan guru dan siswa, dan angket respon siswa.

Alat pengumpul data: butir soal tes, lembar observasi aktivitas siswa, lembar observasi aktivitas guru, dan lembar angket.

\section{f. Analisis Data}

Teknik analisis data pada penelitian ini menggunakan analisis deskriptif kualitatif terhadap data penelitian tindakan kelas dengan tahapan sebagai berikut: menyeleksi, menyederhanakan, mengklasifikasi, memfokuskan, mengorganisasi (mengaitkan gejala secara sistematis dan logis), membuat abstraksi atas kesimpulan makna hasil analisis. Model analisis kualitatif adalah model Miles \& Hubberman (1992: 20) yang meliputi: reduksi data (memilah data penting, relevan, dan bermakna dari data yang tidak berguna), sajian deskriptif (narasi, visual gambar, 
tabel) dengan alur sajian yang sistematis dan logis, penyimpulan dari hasil yang disajikan berupa dampak PTK dan efektivitasnya.

\section{g. Indikator Keberhasilan}

Kriteria keberhasilan dalam penelitian ini adalah (1) rata-rata pengamatan aktivitas siswa kelas IXB SMP Negeri 4 Yogyakarta semester 1 tahun pelajaran 2018/2019 materi Transformasi menggunakan DBL berbantuan GeoGebra tiap pertemuan pada siklus minimal $80 \%$, (2) rata-rata pengamatan aktivitas guru di kelas 9B SMP Negeri 4 Yogyakarta semester 1 tahun pelajaran 2018/2019 materi Transformasi menggunakan DBL berbantuan GeoGebra tiap pertemuan pada siklus minimal $80 \%$, (3) rata-rata hasil angket siswa yang menjawab "ya" pada tiap siklus adalah $80 \%$ dan (4) peningkatkan rata-rata pre tes ke pos tes hasil belajar siswa SMP Negeri 4 Yogyakarta kelas IXB semester 1 tahun pelajaran 2018/2019 materi transformasi menggunakan DBL berbantuan GeoGebra minimal 50,00.

\section{Pembahasan}

a. Deskripsi Kondisi Awal

Menurut pengalaman peneliti, sebagian besar siswa menganggap matematika sebagai pelajaran yang sulit dipelajari. Salah satu penyebabnya, dalam proses pembelajarannya sering disajikan dalam bentuk formal dan abstrak. Sifat abstrak ini menyebabkan banyak siswa mengalami kesulitan dalam memahami materi matematika. Materi kelas IX semester 1 sebelum Penilaian Tengah Semester (PTS) bersifat abstrak yaitu: (1) Bilangan berpangkat dan bentuk akar; (2) Persamaan kuadrat dan (3) Fungsi kuadrat.

Dari hasil PTS semester 1 tahun ajaran 2018/2019, rata-rata untuk mata pelajaran matematika dari 5 kelas, kelas IXA s.d. IXE adalah
56,70. Hasil ini relatif jauh lebih rendah dari Kriteria Ketuntasan Minimal (KKM) sekolah yaitu 80. Ratarata terendah dari 5 kelas tersebut adalah kelas IXB yaitu 46,09. Hasil ini tentu harus segera ditindaklanjuti, agar nilai siswa meningkat terutama pada materi selanjutnya setelah PTS. Materi selanjutnya setelah PTS adalah Transformasi. Tindaklanjut yang utama di kelas IXB, karena kelas ini memiliki nilai rata-rata PTS terendah dari 5 kelas.

Pada kelas IXB dilaksanakan tindakan kelas dengan menerapkan model DBL berbantuan GeoGebra untuk meningkatkan hasil belajar siswa kelas IXB materi transformasi. Materi transformasi yang tergolong abstrak diharapkan dapat dilaksanakan tidak formal karena melibatkan siswa dalam proses kegiatan mental melalui tukar pendapat, dengan diskusi, seminar, membaca sendiri dan mencoba sendiri, agar anak dapat belajar sendiri. Siswa secara aktif menemukan sendiri konsep-konsep dalam pembelajaran dengan bantuan Software GeoGebra dan pengarahan secukupnya dari guru, sehingga pada akhirnya pada materi ini nilai siswa meningkat.

\section{b. Deskripsi Siklus 1}

Siklus 1 dilaksanakan sesuai fase pembelajaran $D B L$, yaitu Fase 1: Menyajikan pertanyaan atau masalah, Fase 2: Membuat hipotesis, Fase 3: Merancang percobaan, Fase 4: Melakukan percobaan untuk memperoleh informasi, Fase 5: Mengumpulkan dan menganalisis data, dan Fase 6: Membuat kesimpulan.

Hasil pengamatan pertemuan 1 siklus 1 sebagai berikut. Selama proses pembelajaran berlangsung guru dan kolaborator melakukan pengamatan terhadap kinerja kelompok dan individu aspek aktivitas siswa dari 
awal sampai akhir pembelajaran. Selain itu kolaborator juga mengamati aktivitas yang dilakukan guru pada pertemuan 1 ini.

Hasil pengamatan peneliti, peserta sangat antusias terhadap penggunaan Software GeoGebra. Siswa ingin segera menyelesaikan permasalahan berbentuk pertanyaan dari guru. Tetapi tidak semua siswa menulis pertanyaan tersebut.

Tiga kelompok, yaitu kelompok 5, 6 dan 7, tidak membuat hipotesis dari pertanyaan. Komentar mereka adalah ingin langsung mempraktikan menggunakan Software GeoGebra. Empat kelompok, kelompok 5, 6, 7, dan 8, tidak membuat langkahlangkah penyelesaian. Alasan mareka adalah terlalu lama, mereka hanya ingin mengucapkan saja langkahlangkah tersebut kepada guru.

Karena satu kelompok terdapat satu laptop, maka yang terjadi adalah siswa berebut ingin mempraktikkan menyelesaikan masalah menggunakan Software GeoGebra. Menurut pengakuan siswa, dua kelompok yakni kelompok 5 dan 7 tidak dapat menyelesaikan semua masalah yang diajukan karena kekurangan waktu. Tiga kelompok dapat menyajikan hasil kerja kelompoknya yaitu kelompok 1, 3, dan 4. Guru menjanjikan pada pertemuan berikutnya akan diusahakan lima kelompok yang belum presentasi untuk presentasi. Sebagian besar siswa mengangkat tangan ingin menjawab kuis yang diajukan guru pada akhir pembelajaran. Akan tetapi beberapa siswa menjawabnya belum benar.

Hasil refleksi peneliti dan kolaborator adalah: (1) pembelajaran ini siswa terlihat lebih siap dan bergairah menggunakan model discovery learning berbantuan Software GeoGebra (2) usaha untuk menambah laptop tidak berhasil maka walaupun komputer tiap kelompok hanya satu, siswa akan difahamkan agar tidak terjadi rebutan dan masalah yang diajukan selesai semua. (3) Siswa diberi pemahaman tentang pentingnya membuat hipotesis dan membuat langkah-langkah penyelesaian dengan baik. (4) Pada pertemuan berikutnya diusahakan lima kelompok yang belum presentasi untuk presentasi.

Hasil pengamatan pertemuan 2 siklus 1 sebagai berikut. Semua kelompok membuat hipotesis dari pertanyaan dan membuat langkah-langkah penyelesaian. Suasana berebut laptop masih ada pada dua kelompok yaitu kelompok 5 dan 7 . Karena keterbatasan waktu satu kelompok belum presentasi. Sebagian besar siswa mengangkat tangan ingin menjawab kuis yang diajukan guru pada akhir pembelajaran. Namun ada satu siswa yang menjawab kuis jawabannya belum benar.

Hasil pengamatan kolaborator terhadap aktivitas siswa dan guru yang dituangkan dalam instrumen observasi siswa dan guru adalah ratarata pengamatan aktivitas siswa materi refleksi dan translasi menggunakan DBL berbantuan GeoGebra pada siklus 1, 86\%. Hasil ini sudah melampaui indikator keberhasilan penelitian yaitu $80 \%$.

Rata-rata pengamatan aktivitas guru materi refleksi dan translasi menggunakan DBL berbantuan GeoGebra pada siklus 1, 82\%. Hasil ini sudah melampaui indikator keberhasilan penelitian yaitu $80 \%$. Sedangkan rata-rata hasil angket siswa yang menjawab "ya" pada siklus 1 ini adalah 72,28\%. Angka ini masih di bawah indikator keberhasilan penelitian yaitu $80 \%$.

Nilai LKS siklus satu untuk tiap kelompok adalah kelompok 1 84,3, kelompok 2 99,5, kelompok 3 73, kelompok 4 96,5, kelompok 5 87, 
kelompok 6 96,5, kelompok 780 dan kelompok 8 84. Rata-ratanya adalah 87,6 .

Rata-rata pre tes siklus 1 adalah 31 , 68. Rata-rata pos tes 94,09. Kenaikannya adalah 62,41. Hal ini sudah lebih tinggi dari indikator keberhasilan penelitian ini yaitu 50,00 .

Terdapat unsur yang belum memenuhi indikator keberhasilan penelitian yaitu rata-rata hasil angket siswa yang menjawab "ya" pada siklus 1 ini adalah 72,28\%. Angka ini masih di bawah indikator keberhasilan penelitian yaitu $80 \%$. Temuan dari kolaborator adalah adanya satu kelompok, kelompok 6, yang tidak presentasi, maka pada siklus berikutnya diusahakan semua kelompok dapat presentasi. Berdasarkan hasil tersebut maka peneliti dan kolaborator sepakat melaksanakan siklus 2 .

\section{c. Deskripsi Siklus 2}

Siklus 2 juga dilaksanakan sesuai fase pembelajaran $D B L$, yaitu Fase 1: Menyajikan pertanyaan atau masalah, Fase 2: Membuat hipotesis, Fase 3: Merancang percobaan, Fase 4: Melakukan percobaan untuk memperoleh informasi, Fase 5: Mengumpulkan dan menganalisis data, dan Fase 6: Membuat kesimpulan.

Hasil pengamatan pertemuan 1 siklus 2 sebagai berikut. Semua kelompok membuat hipotesis dari pertanyaan dan membuat langkah-langkah penyelesaian. Tidak ada siswa yang berebut laptop. Siswa sabar menanti gilirannya untuk menyelesaikan masalah dengan Software GeoGebra. Siswa sudah lebih lancar menggunakan Software GeoGebra. Empat kelompok yang presentasi yaitu kelompok 3, 4, 6 dan 8 . Sebagian besar siswa mengangkat tangan ingin menjawab kuis yang diajukan guru pada akhir pembelajaran. Para siswa yang menjawab kuis jawabannya semua benar.

Hasil refleksi peneliti dan kolaborator adalah (1) siswa lebih tenang, teratur dan disiplin dalam mengikuti fase-fase pembelajaran DBL dari pada siklus 1; (2) rata-rata siswa juga lebih lancar menggunakan software GeoGebra dibandingan dengan pada siklus 1 ; (3) Setiap kelompok selesai menjawab atau menyelesaikan semua masalah yang diajukan.; (4) semua kelompok selesai mengerjakan LKS

kelompok yang presetasi yaitu kelompok 3, 4, 6 dan 8, juga lebih lancar dalam menyampaikan penyelesaian masalah menggunakan software GeoGebra. Tepuk tangan lebih meriah disampaikan kepada kelompok-kelompok yang presentasi; (5) Banyak siswa mengeksplor kemampuan menggunakan software GeoGebra, sehingga tampilan lebih baik, lebih cepat dan lebih jelas.

Hasil pengamatan pertemuan 2 siklus 2 sebagai berikut. Empat kelompok yang presetasi yaitu kelompok 1, 2, 5, dan 7 berjalan lancar. Semua kelompok presentasi. Semua siswa mengangkat tangan ingin menjawab kuis yang diajukan guru pada akhir pembelajaran. Para siswa yang menjawab kuis jawabannya semua benar. Eksplor siswa terhadap penggunaan software GeoGebra, beberapa merupakan hal baru bagi guru.

Hasil pengamatan kolaborator terhadap aktivitas siswa dan guru yang dituangkan dalam instrumen observasi siswa dan guru adalah ratarata pengamatan partisipasi siswa materi rotasi dan dilatasi menggunakan DBL berbantuan GeoGebra pada siklus 2, 97\%. Hasil ini sudah melampaui indikator keberhasilan penelitian yaitu $80 \%$. 
Rata-rata pengamatan aktivitas guru materi rotasi dan dilatasi menggunakan DBL berbantuan menggunakan GeoGebra pada siklus 2 95\%. Hasil ini sudah melampaui indikator keberhasilan penelitian yaitu $80 \%$. Sedangkan rata-rata hasil angket siswa yang menjawab "ya" pada siklus 2 ini adalah 96,91\%. Angka ini sudah di atas indikator keberhasilan penelitian yaitu $80 \%$.

Nilai LKS siklus dua untuk tiap kelompok adalah kelompok 1, 100, kelompok 2, 100, kelompok 3, 97,5, kelompok 4, 100, kelompok 5, 100, kelompok 6, 100, kelompok 7, 100 dan kelompok 8, 97,5. Rata-ratanya adalah 99,375.

Rata-rata pre tes siklus 2 adalah 30 , 88. Rata-rata pos tes 93,38. Kenaikannya adalah 62,50. Hal ini sudah lebih tinggi dari indikator keberhasilan penelitian ini yaitu 50,00 .

Refleksi pertemuan 2 siklus 2 adalah semua unsur sudah memenuhi indikator keberhasilan penelitian. Semua kelompok presentasi. Berdasarkan hasil tersebut maka peneliti dan kolaborator sepakat data sudah jenuh, sehingga penelitian berhenti sampai dengan siklus 2 .

\section{d. Pembahasan Tiap Siklus dan Antarsiklus}

Pada siklus 1, beberapa tahapan dari DBL ada yang tidak dilakukan oleh siswa, misalnya pada pertemuan 1 tidak semua siswa menulis pertanyaan, tiga kelompok, yaitu kelompok 5, 6 dan 7, tidak membuat hipotesis dari pertanyaan, dan empat kelompok, kelompok 5, 6, 7, dan 8, tidak membuat langkah-langkah penyelesaian. Hal ini justru membuat kerja kelompok tersebut menjadi relatif lebih lama selesai dibanding kelompok lain. Menurut pengakuan siswa, dua kelompok, kelompok 5 dan 7 tidak dapat menyelesaikan semua masalah yang diajukan karena kekurangan waktu.

Pada kegiatan menjawab kuis di akhir pembelajaran, semakin lama semakin banyak siswa yang mengangkat tangan ingin menjawab dan jawabannya semakin banyak yang benar dan menjawab lebih lancar dan baik. Pada siklus 1 pertemuan 1, sebagian besar siswa mengangkat tangan ingin menjawab kuis yang diajukan guru pada akhir pembelajaran. Akan tetapi beberapa siswa menjawabnya belum benar. Siklus 1 pertemuan 2, sebagian besar siswa mengangkat tangan ingin menjawab kuis yang diajukan guru pada akhir pembelajaran. tetapi ada satu siswa yang menjawab kuis jawabannya belum benar. Siklus 2 pertemuan 1, sebagian besar siswa mengangkat tangan ingin menjawab kuis yang diajukan guru pada akhir pembelajaran. Para siswa yang menjawab kuis jawabannya semua benar. Siklus 2 pertemuan 2, semua siswa mengangkat tangan ingin menjawab kuis yang diajukan guru pada akhir pembelajaran. Para siswa yang menjawab kuis jawabannya semua benar.

Keadaan yang sudah disampaikan tersebut sesuai dengan pengertian Discovery Learning, yang disampaikan Sumardyono dkk, (2018: 33), yaitu materi yang akan disampaikan tidak dalam bentuk final akan tetapi siswa didorong untuk mengidentifikasi apa yang ingin diketahui, dilanjutkan dengan mencari informasi sendiri kemudian mengorganisasi atau membentuk apa yang mereka ketahui dan pahami dalam suatu bentuk akhir.

Dengan demikian siswa bergairah mengikuti kegiatan pembelajaran dan semakin lama semakin menikmati cara belajar mereka sendiri. Dampak akhirnya mereka semakin mudah memahami materi yang dibahas. 
Hasil pengamatan peneliti, peserta sangat antusias terhadap penggunaan Software GeoGebra. Siswa ingin segera menyelesaikan permasalahan berbentuk pertanyaan dari guru. Pada siklus 1, tiga kelompok, yaitu kelompok 5, 6 dan 7, tidak membuat hipotesis dari pertanyaan. Komentar mereka adalah ingin langsung mempraktikan menggunakan Software GeoGebra. Empat kelompok, kelompok 5, 6, 7, dan 8, tidak membuat langkah-langkah penyelesaian. Alasan mereka adalah terlalu lama, mereka hanya ingin mengucapkan saja langkah-langkah tersebut kepada guru. Pada siklus 2 masalah kelompok yang tidak membuat hipotesis dan tidak menulis langkah-langkah penyelesaian sudah teratasi.

Karena satu kelompok terdapat satu laptop, maka yang terjadi adalah siswa berebut ingin mempraktikkan menyelesaikan masalah menggunakan Software GeoGebra. Menurut pengakuan siswa dua kelompok, kelompok 5 dan 7 tidak dapat menyelesaikan semua masalah yang diajukan karena kekurangan waktu. Pada siklus 2, dengan pemahaman dari guru, berebut laptop sudah tidak terjadi lagi. Pada siklus 2 pertemuan satu banyak siswa mengeksplor kemampuan menggunakan software GeoGebra, sehingga tampilan lebih baik, lebih cepat dan lebih jelas. Bahkan pada pertemuan dua, eksplorasi siswa terhadap penggunaan software GeoGebra, beberapa merupakan hal baru bagi guru, sehingga pada siklus 2 pertemuan 1, terjadi kelompok yang presentasi yaitu kelompok 3, 4, 6 dan 8, selain lebih lancar dalam menyampaikan penyelesaian masalah menggunakan software GeoGebra juga tepuk tangan lebih meriah disampaikan kepada kelompokkelompok yang presentasi tersebut.
Hal-hal tersebut bisa terjadi sesuai dengan beberapa kelebihan dari Aplikasi GeoGebra yang menurut Maxrizal (2010: 18) adalah:

1) Icon-icon disajikan dalam ukuran besar untuk menghindari kesalahan dalam memilih menu.

2) Semua objek dapat diberi label atau keterangan, baik itu berupa titik, garis, bidang sudut dan sebagainya.

3) Objek dapat digeser, dicerminkan, diputar dan diperbesar

4) Warna objek dapat dirubah dengan 41 pilihan warna agar mudah dibedakan dengan objek lain.

Hasil observasi rata-rata pengamatan aktivitas siswa menggunakan DBL berbantuan GeoGebra pada siklus 1, $86 \%$, siklus 2, 97\%. Keadaan ini berarti terdapat peningkatan $11 \%$ dan hasil siklus 1 maupun 2 sudah melampaui indikator keberhasilan penelitian yaitu $80 \%$.

Tabel 1 Hasil observasi aktivitas siswa antarsiklus

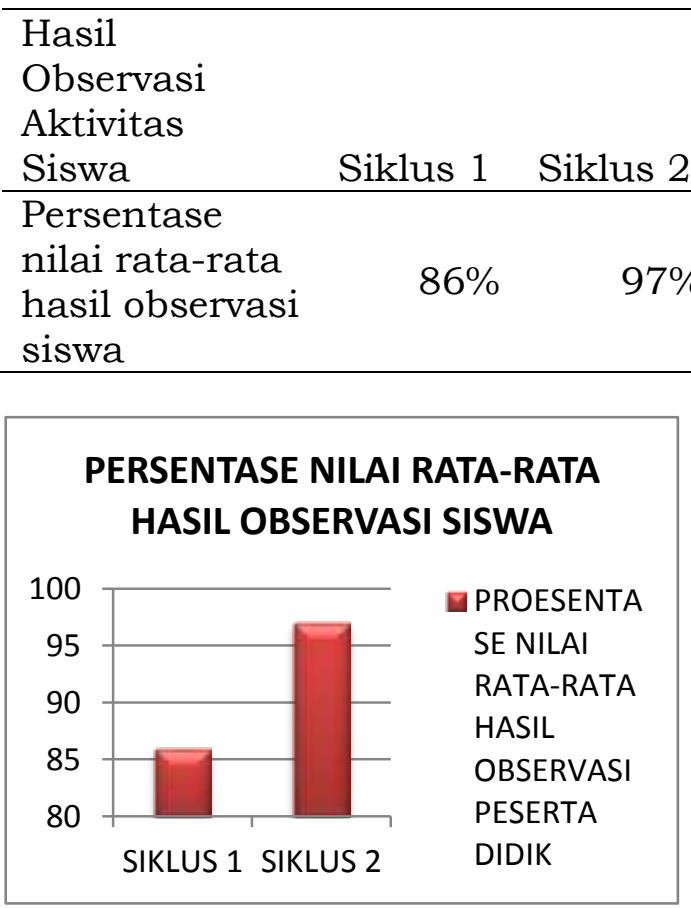

Gambar 1 Hasil observasi aktivitas siswa antarsiklus 
Rata-rata pengamatan aktivitas guru menggunakan DBL berbantuan GeoGebra pada siklus 1, 82\% dan siklus 2, 95\%. Terjadi peningkatan $13 \%$. Hasil siklus 1 maupun 2 sudah melampaui indikator keberhasilan penelitian yaitu $80 \%$. Hasil ini dapat disajikan menggunakan tabel dan diagram sebagai berikut.

Tabel 2 Hasil observasi aktivitas guru antarsiklus

\begin{tabular}{lll}
\hline $\begin{array}{l}\text { Hasil } \\
\begin{array}{l}\text { Observasi } \\
\text { Aktivitas Guru }\end{array}\end{array}$ & Siklus & Siklus 2 \\
\hline $\begin{array}{l}\text { Persentase } \\
\text { nilai rata-rata }\end{array}$ & $82 \%$ & $95 \%$ \\
$\begin{array}{l}\text { hasil } \\
\text { observasi guru }\end{array}$ & & \\
\hline
\end{tabular}

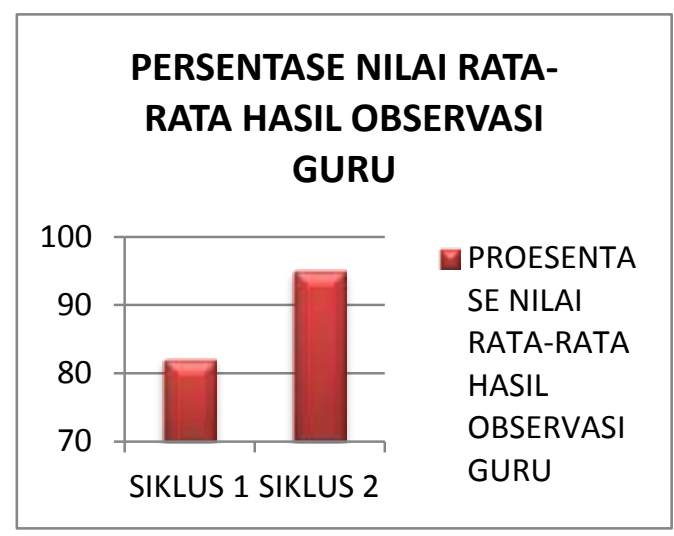

Gambar 2 Hasil observasi aktivitas siswa antarsiklus

Rata-rata hasil angket siswa yang menjawab "ya" pada siklus 1 adalah $72,28 \%$, dan siklus 2 adalah 96,91\%. Siklus 2 sudah di atas indikator keberhasilan penelitian yaitu $80 \%$. Jika hasil ini disajikan menggunakan tabel dan diagram, sebagai berikut.

Tabel 3 Hasil angket siswa antarsiklus

\begin{tabular}{lr}
\hline \multicolumn{2}{c}{ Hasil Angket Siswa } \\
\hline Rata-Rata Siklus 1 & 72,28 \\
Rata-Rata Siklus 2 & 96,91 \\
\hline
\end{tabular}

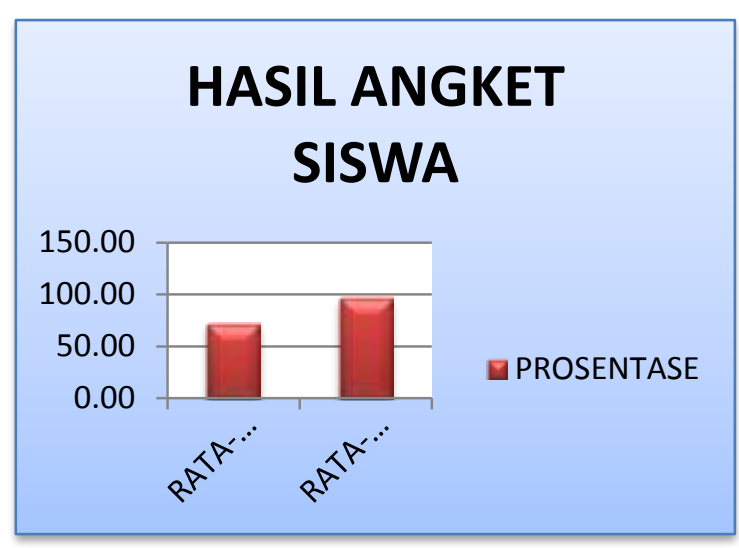

Gambar 3 Hasil angket siswa antarsiklus

Nilai LKS siklus 1 untuk tiap kelompok adalah kelompok 1, 84,3, kelompok 2, 99,5, kelompok 3, 73, kelompok 4, 96,5, kelompok 5, 87, kelompok 6, 96,5, kelompok 7, 80 dan kelompok 8, 84. Rata-ratanya adalah 87,6 . Pada siklus 2 untuk tiap kelompok adalah kelompok 1, 100, kelompok 2, 100, kelompok 3, 97,5, kelompok 4, 100, kelompok 5, 100, kelompok 6, 100, kelompok 7, 100 dan kelompok 8, 97,5. Rata-ratanya adalah 99,375. Jika disajikan menggunakan tabel dan diagram, sebagai berikut.

Tabel 4 Hasil LKS antarsiklus

\begin{tabular}{cccc}
\hline Kelompok & $\begin{array}{c}\text { Nilai } \\
\text { Siklus 1 }\end{array}$ & $\begin{array}{c}\text { Nilai } \\
\text { Siklus 2 }\end{array}$ & Kenaikan \\
\hline 1 & 84,3 & 100 & 15,7 \\
2 & 99,5 & 100 & 0,5 \\
3 & 73 & 97,5 & 24,5 \\
4 & 96,5 & 100 & 3,5 \\
5 & 87 & 100 & 13 \\
6 & 96,5 & 100 & 3,5 \\
7 & 80 & 100 & 20 \\
8 & 84 & 97,5 & 13,5 \\
\hline Rata-Rata & 87,6 & 99,375 & 11,775 \\
\hline
\end{tabular}




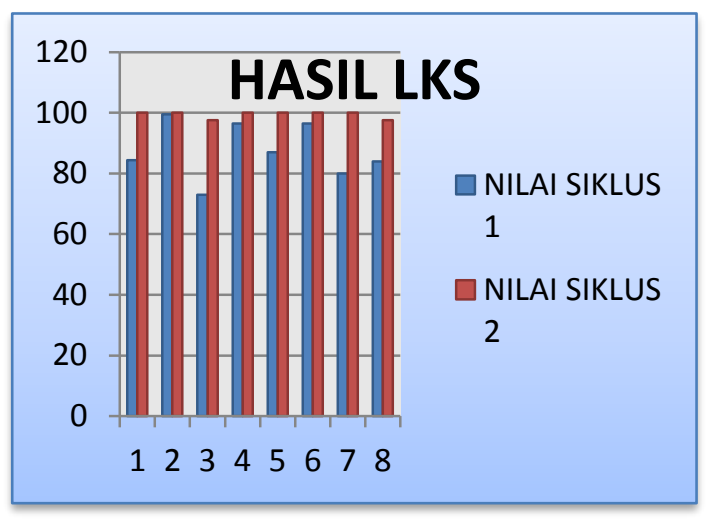

Gambar 4 Hasil LKS antarsiklus

Terlihat bahwa terjadi kenaikan nilai LKS dari siklus 1 ke siklus 2. Ratarata kenaikannya mencapai 11,775 . Kenaikan tertinggi terjadi pada kelompok 3 yaitu 24,5.

Rata-rata pre tes siklus 1 adalah 31 , 68. Rata-rata pos tes 94,09. Kenaikannya adalah 62,41 . Rata-rata pre tes siklus 2 adalah 30, 88. Ratarata pos tes 93,38. Kenaikannya adalah 62,50. Kenaikan ini sudah lebih tinggi dari indikator keberhasilan penelitian ini yaitu 50,00. Penyajian menggunakan tabel dan diagram sebagai berikut.

Tabel 7 Hasil pre tes dan pos tes antarsiklus

\begin{tabular}{rrrr}
\hline & $\begin{array}{l}\text { Rata- } \\
\text { Rata } \\
\text { Siklus }\end{array}$ & \multicolumn{2}{l}{$\begin{array}{l}\text { Rata- } \\
\text { Rata }\end{array}$} \\
& Pre Tes & \multicolumn{1}{l}{ Post Tes } & Kenaikan \\
\hline 1 & 31,68 & 94,09 & 62,41 \\
2 & 30,88 & 93,38 & 62,50 \\
\hline
\end{tabular}

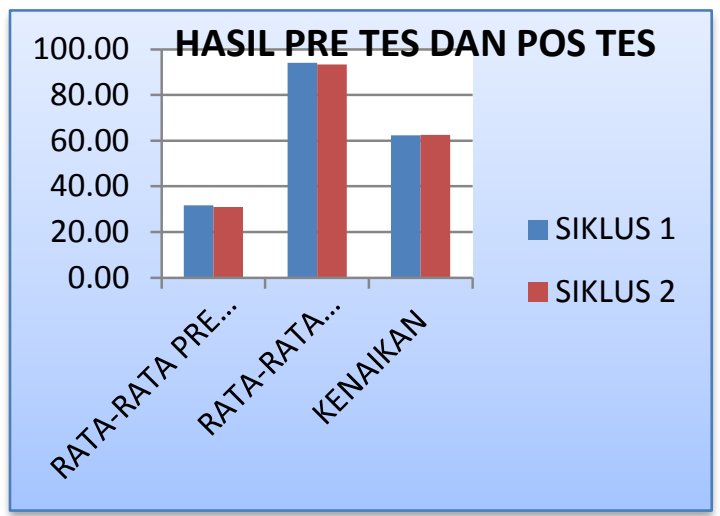

Gambar 7 Hasil Pre tes dan pos tes antarsiklus

\section{e. Kesimpulan Hasil Penelitian}

Terdapat empat kriteria keberhasilan dalam penelitian ini. Kriteria pertama adalah rata-rata pengamatan aktivitas siswa kelas IXB SMP Negeri 4 Yogyakarta semester 1 tahun pelajaran 2018/2019 materi Transformasi menggunakan DBL berbantuan GeoGebra tiap pertemuan pada siklus minimal $80 \%$. Pada kenyataannya hasil observasi ratarata pengamatan aktivitas siswa menggunakan DBL berbantuan GeoGebra pada siklus 1, 86\%, siklus 2, 97\%. Keadaan ini berarti hasil siklus 1 maupun 2 sudah melampaui indikator keberhasilan penelitian yaitu $80 \%$.

Kriteria kedua adalah rata-rata pengamatan aktivitas guru di kelas IXB SMP Negeri 4 Yogyakarta semester 1 tahun pelajaran 2018/2019 materi Transformasi menggunakan DBL berbantuan GeoGebra tiap pertemuan pada siklus minimal $80 \%$. Kenyataannya adalah rata-rata pengamatan aktivitas guru menggunakan DBL berbantuan GeoGebra pada siklus1, 82\% dan siklus 2, 95\%. Terjadi peningkatan 13\%. Hasil siklus 1 maupun 2 sudah melampaui indikator keberhasilan penelitian yaitu $80 \%$.

Kriteria ketiga adalah rata-rata hasil angket siswa yang menjawab "ya" pada tiap siklus adalah $80 \%$. Kejadian sesungguhnya adalah rata-rata hasil angket siswa yang menjawab "ya" pada siklus 1 adalah $72,28 \%$, dan siklus 2 adalah 96,91\%. Siklus 2 sudah di atas indikator keberhasilan penelitian yaitu $80 \%$.

Kriteria keempat adalah peningkatkan rata-rata pre tes ke pos tes hasil belajar siswa SMP Negeri 4 Yogyakarta kelas IXB semester 1 tahun pelajaran 2018/2019 materi transformasi menggunakan DBL berbantuan GeoGebra minimal 50,00. Kajadian di lapangan adalah rata-rata pre tes 
siklus 1 adalah 31 , 68. Rata-rata pos tes 94,09. Kenaikannya adalah 62,41. Rata-rata pre tes siklus 2 adalah 30 , 88. Rata-rata pos tes 93,38. Kenaikannya adalah 62,50. Jadi kenaikan ini sudah lebih tinggi dari indikator keberhasilan penelitian yaitu 50,00.

Keempat kriteria keberhasilan penelitian ini terpenuhi. Dengan demikian maka dapat disimpulkan bahwa penerapan model DBL berbantuan GeoGebra dapat meningkatkan hasil belajar siswa kelas IXB SMP Negeri 4 Yogyakarta materi transformasi semester 1 tahun pelajaran 2018/2019.

\section{Simpulan dan Saran}

\section{Simpulan}

Berdasarkan uraian hasil penelitian maka dapat disimpulkan bahwa:

1) Penerapan model DBL berbantuan GeoGebra dapat meningkatkan aktivitas siswa kelas IXB SMP Negeri 4 Yogyakarta materi transformasi semester 1 tahun pelajaran 2018/2019.

2) Penerapan model DBL berbantuan GeoGebra dapat meningkatkan hasil belajar siswa kelas IXB SMP Negeri 4 Yogyakarta materi transformasi semester 1 tahun pelajaran 2018/2019.

\section{Saran}

Berdasarkan pengamalan melaksanakan penelitian ini maka ada beberapa saran yang dapat disampaiakan.

1) Bagi siswa jika semangat beraktivitas pada pembelajaran dengan menerapan model DBL berbantuan GeoGebra maka akan meningkatkan hasil belajar.

2) Bagi guru jika penerapan model DBL berbantuan GeoGebra dilaksanakan sesuai urutan aspek pada DBL dan mengeksplor terus kemampuan menggunakan GeoGebra maka dapat meningkatkan aktivitas dan hasil belajar siswa.

3) Bagi sekolah jika mengkondisikan khususnya guru matematika untuk melaksanakan pembelajaran menggunakan model DBL berbantuan GeoGebra dalam pembelajaran matematika, maka dapat meningkatkan aktivitas dan hasil belajar siswa, menghadirkan pembelajaran berkualitas sesuai tuntutan era revolusi 4.0 .

\section{Daftar Pustaka}

Afiatin, T., (2011). Pendidikan Karakter Remaja dalam Keluarga, dalam Faturochman dkk, (2012). Psikologi untuk Kesejahteraan Masyarakat, Yogyakarta: Universitas Gadjah Mada Pustaka Pelajar

De Jong, Ton \& Wuter R. van Joolingen. (1998). Scientific Discovery Learning With Computer Simulation of Conceptual Domains. Review of Educational Research. 68 (2): 179-201

Judith dan Markus Hohenwarter and team. (2008). Introduction to GeoGebra 4.4. USA: International GeoGebra Institute

Kemmis dan Mc. Taggart. (2010). Melaksanakan PTK Itu Mudah. Jakarta: PT Bumi Aksara. 
Kolb, D.A. (1984). Experimental Learning Experience as the Source of Learning and Development. New Jersey: Prentice Hall. Inc

Maxrizal (2010). Skripsi: Penggunaan Software Geogebra Dengan Metode Penemuan Terbimbing Untuk Meningkatkan Motivasi Belajar Pada Materi Segiempat Bagi Siswa Kelas VIIC SMP N 2 Depok. Yogyakarta: UNY tidak diterbitkan.

Miles, Matthew dan Huberman, A. Michael. (1992). Analisis Data Kualitatif: Buku Sumber Tantang Metode-Metode Baru. Jakarta:UI Press.

Roestiyah NK.(2001). Strategi Belajar Mengajar, Jakarta: Rineka Cipta

Sanjaya, Wina. (2008). Perencanaan dan desain sistem pembelajaran. Jakarta: Kencana Prenada Media Group.

Tim Pengembang MKDP Kurikulum dan Pembelajaran. (2011). Kurikulum dan Pembelajaran. Jakarta : Rajawali Press. 